\title{
DAYS ON FEED AND SEX EFFECTS ON LIVE WEIGHT AND CARCASS TRAITS MEASURED BY ULTRASOUND
}

\author{
Saulo da Luz e Silva*; Evaldo Antonio Lencioni Titto; Paulo Roberto Leme; Luciane Silva \\ Martello; Angélica Simone Cravo Pereira; Rafael Martins Titto; José Carlos Machado Nogueira \\ Filho; Albino Luchiari Filho
}

USP/FZEA - Depto. Zootecnia, C.P. 23 - 13635-000 - Pirassununga, SP - Brasil.

*Corresponding author<sauloluz@usp.br>

\begin{abstract}
There is a paucity of information in the literature on body composition changes in Nellore cattle and its crosses, mainly on heifers and intact males. Ultrasound is a useful, low cost tool to easily obtain this information, with minimal animal stress. Effects of sex and days on feed on live weight (LW) and ultrasound Longissimus muscle area (ULMA) and subcutaneous fat thickness (UFAT) measurements were evaluated in F1 Piedmont $\times$ Nelore, 27 heifers (HF) and 27 intact males (IM). HF and IM had an initial LW of $256 \pm 5.6$ and $265 \pm 5.6 \mathrm{~kg}$, respectively, and were fed a diet containing 77\% TDN for 131 days. LW, ULMA, and UFAT were evaluated at 28-d intervals. Interactions between sex and days on feed were found for all traits studied. LW increased linearly with days on feed, and IM had greater LW than HF throughout the trial. Mean initial ULMA was 55.8 and $55.5 \mathrm{~cm}^{2}$ for HF and IM, respectively, and increased linearly until the end of the experiment (78.7 and $82.8 \mathrm{~cm}^{2}$, respectively). IM showed higher ULMA than HF only in the last measurement. Initial UFAT averaged 0.04 and $0.4 \mathrm{~mm}$ for IM and HF, respectively, and increased linearly during the feeding period (2.4 and $4.3 \mathrm{~mm}$, respectively). UFAT was higher $\mathrm{n} \mathrm{HF}$ than in IM during the entire experimental period. IM showed faster growth rates and protein accretion than HF in the Longissimus muscle. HF showed faster subcutaneous fat accretion.
\end{abstract}

Key words: backfat thickness, beef, in vivo evaluation, ribeye area

\section{EFEITO DOS DIAS EM CONFINAMENTO E SEXO SOBRE O PESO VIVO E AS CARACTERÍSTICAS DE CARCAÇA, MEDIDAS POR ULTRA-SONOGRAFIA}

\begin{abstract}
RESUMO: Existem poucos dados na literatura sobre as alterações na composição corporal de bovinos Nelore e seus cruzamentos, especialmente em relação a novilhas (NOV) e machos inteiros (MI). A ultra-sonografia é uma ferramenta útil para obter essa informação de forma fácil, com mínimo distúrbio ao animal e a baixo custo. Efeitos do sexo e dias de confinamento sobre o peso vivo (PV) e a área do músculo Longissimus dorsi (AOLU) e a espessura de gordura subcutânea (EGSU) medidas por ultra-som, foram avaliadas em 27 novilhas e 27 machos inteiros, F1 Piemontês $\times$ Nelore. NOV e MI com PV inicial de $256 \pm 5,6$ e $265 \pm 5,6 \mathrm{~kg}$, respectivamente, foram confinados com uma dieta contendo $77 \%$ de NDT, durante 131 dias. O PV, a AOLU e a EGSU foram avaliadas a cada 28 dias aproximadamente. Foi observada uma interação entre sexo e dias de confinamento para todas as características avaliadas. O PV aumentou linearmente com os dias de confinamento e MI apresentaram maior PV que as NOV desde o início do experimento. A AOLU média inicial foi 55,8 e $55,5 \mathrm{~cm}^{2}$ nas NOV e MI, respectivamente, aumentando linearmente até o final do confinamento (78,7 e 82,8 $\mathrm{cm}^{2}$, respectivamente). Em relação ao efeito do sexo, MI tiveram maior AOLU que NOV somente na última medida. A EGSU inicial foi 0,04 e $0,4 \mathrm{~mm}$ para $\mathrm{MI}$ e NOV, respectivamente e aumentaram linearmente durante e período de confinamento (2,4 e 4,3 mm, respectivamente). NOV tiveram maior EGSU desde o início até o final do período experimental. MI tiveram maiores taxas de crescimento do PV e AOLU que NOV, no entanto, estas tiveram maior taxa de crescimento da EGSU.

Palavras-chave: espessura de gordura subcutânea, bovinos, avaliação in vivo, área de olho de lombo
\end{abstract}

\section{INTRODUCTION}

Ultrasound technology has been widely used to estimate live carcass traits in beef cattle. Research has shown that ultrasound measurements of Longissimus muscle area and subcutaneous fat thickness obtained by trained personnel, show high correlations with actual car- cass values (Crews et al., 2002; Silva et al., 2003; Suguisawa et al., 2003).

Ultrasound is also a useful tool to study changes in animal tissues composition under different nutritional and behavioral regimes, with minimal animal stress, and is a valuable tool in genetic improvement programs where carcass and production traits are evaluated at young ages. 
In addition, ultrasound measurements are useful to predict the finishing degree, in order to avoid over or under conditioned animals at slaughter plants. These live evaluations are particularly important in the Nellore breed and its crosses, which constitute the major part of the Brazilian herd.

Crossbreeding Piedmont with Nellore cattle is increasing in Brazil mainly due to a high carcass dressing percentage and retail yield. However, a high quality carcass should have enough backfat cover to ensure its preservation and the maintenance and desirable traits to consumers (Suguisawa et al., 2003). However, Piedmont $\times$ Nellore crosses show low fat accretion and frequently do not reach the minimum fat cover required by processing plants.

The use of ultrasound technique has increased in the last few years in Brazil, especially in Nellore and Nellore crosses (Karsburg et al., 2003; Silva et al., 2002, 2003; Suguisawa et al., 2003). However, information is still scarce on carcass traits of Nellore and its crosses, regarding intact males, heifers and during their growth cycle. This information will help producers to supply better finished-animals to the packing plants. The objective of this work was to study the effects of sex and days on feeding on live weight and on loin area and subcutaneous fat thickness evaluated by ultrasound in intact F1 Piedmont $\times$ Nellore males and heifers.

\section{MATERIAL AND METHODS}

This work was carried out at Pirassununga, SP, Brasil (21 ${ }^{\circ} 59^{\prime} \mathrm{S}, 4^{\circ} 26^{\prime} \mathrm{W}$; altitude $\left.634 \mathrm{~m}\right)$. Twenty seven intact males and 27 heifers from crossbreeding of Italian Piedmont bulls and Nellore cows, raised under grazing conditions, were weaned and allotted in 18 pens, with three animals of the same sex each. Animals were fed a high concentrate diet (Table 1), one morning meal.

Table 1 - Diet composition.

\begin{tabular}{lc}
\hline Ingredient & Dry matter \\
\hline Corn silage & 21.8 \\
\hline Soybean meal $(49 \%)$ & 3.0 \\
Corn grain & 42.7 \\
Urea & 0.985 \\
Ammonium sulphate & 0.05 \\
\hline Potassium chloride & 0.2 \\
Mineral mix & 0.6 \\
Limestone & 0.6 \\
Monensina sódica & 0.027 \\
\hline Nutrient & \\
\hline Crude protein & 13.8 \\
\hline TDN & 77.2 \\
\hline
\end{tabular}

${ }^{1}$ Weiss et al. (1992).
Proximate analyses of diets were done according to Silva (1998). The initial mean shrunk body weight of intact males and heifers was $265 \pm 5.6$ and $256 \pm 5.6 \mathrm{~kg}$, respectively.

After 28 days of adaptation period, animals were weighed and ultrasound measurements of Longissimus muscle area (ULMA) and subcutaneous fat thickness (UFAT) were taken between the 12th and 13th ribs using a Pie Medical Scanner 200 Vet real-time device (Pie Medical Inc., Maastricht, The Netherlands) equipped with a $3.5 \mathrm{MHz}, 18 \mathrm{~cm}$ linear array and acoustic guide attached to it. Vegetable oil was used as a couplant to obtain adequate acoustic contact. Images were saved on a personal computer and interpreted using EView ${ }^{\circledR}$ software (Pie Medical Inc., Maastricht, The Netherlands).

Statistical analyses were conducted using the Mixed procedure of SAS (SAS Inst. Inc., Cary, NC) with sex, days on feed and interaction as main factors. Live weight, ULMA, and UFAT were analyzed as repeated measurements over time. Sex within pen and animal within sex and pen were the random variables. Covariance structures were modeled; the best model fitted to data (heterogeneous autoregressive) was applied. Orthogonal polynomials were used to determine linear, quadratic and cubic effects of time on feed. Genetic and environmental effects were not considered in the modeling process.

\section{RESULTS AND DISCUSSION}

The weight growth curve for intact males and heifers during the trial period is presented in Figure 1. Interaction $(P<0.0001)$ between sex and time on feed was observed for live weight. Intact males were heavier than heifers at the beginning of the experiment $(P=$ $0.0414)$; greater difference was observed at 27 days on feeding $(P=0.0023)$. Differences in LW between sex at 55 days of feeding and at the end of the trial were highly significant $(P<0.0001)$. Live weight increased linearly $(P<0.0001)$ along days on feeding for both intact males and heifers (Table 2).

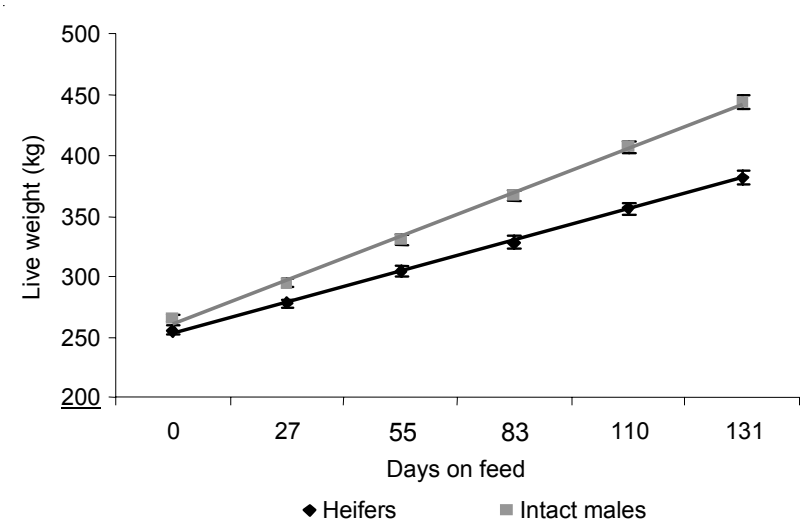

Figure 1 - Live weight means and standard errors as a function of days on feeding. 
An interaction was found between sex and days on feed for ULMA $(P=0.0130)$. ULMA was not different between intact males and heifers from the beginning of the study until 110 days on feeding (Figure 2), although there was a trend $(P=0.1017)$ for intact males to have higher ULMA than heifers at the 110th day on feeding. At the last measurement, males had a higher ULMA than heifers $(P=0.0405)$. These results do not agree with those found by Crews et al. (2002), who reported greater ULMA for Continental $\times$ British bulls than for heifers at weaning, yearling, and slaughter ages.

The ULMA of both intact males and heifers increased linearly $(P<0.0001)$ with days on feeding (Table 2 ) with a higher accretion rate for intact males than heifers $(P=0.0047)$. Similar results were found by Silva (2002) who reported a linear increase in ULMA of Nellore young bulls fed four concentrate levels, from post-weaning to slaughter. Although both studies found a linear increase in Longissimus area, the rate of deposition in the present experiment $\left(0.205 \mathrm{~cm}^{2}\right.$ day $\left.^{-1}\right)$ was greater than the one reported by Silva (2002) for Nellore young bulls fed an $80 \%$ concentrate diet $\left(0.151 \mathrm{~cm}^{2}\right.$ day $\left.^{-1}\right)$. It was expected that Piedmont $\times$ Nellore crosses would have greater muscle area than Nellore pure breed because of the high muscle development potential of Piedmont breed and the heterozygotic effect of crossbreeding.

Longissimus area does not increase linearly during the animal's life, and its growth rate decreases with increasing age and/or weight (Owens \& Gardner, 1999). A quadratic increase in ULMA would have probably occurred have the animals being fed for a longer period. This effect was observed in a study of Silva et al. (2004) with Brangus intact males, probably resulting from the early maturity of Brangus compared to Nellore and Piedmont $\times$ Nellore crosses. Nash et al. (2000) also found a linear increase in ULMA in Limousin-Angus-crossbred heifers under feedlot conditions.

An interaction $(P<0.0001)$ was observed between sex and days on feeding in UFAT (Figure 3 ). Heifers had a greater UFAT than males at the first $(P=$ $0.0095)$, second $(P=0.0002)$, and last four measurements $(P<0.0001)$. Working with Nellore and a Nellore cross,
Luchiari Filho (1986) found that heifers showed greater subcutaneous fat thickness than intact males. Crews et al. (2002) did not find differences in UFAT of heifers and bulls at weaning; however, at the yearling and pre-slaughter ages, heifers had more subcutaneous fat than bulls.

Initial UFAT values were low for both heifers and intact males, as reported in previous studies with Nellore cattle (Silva, 2002; Suguisawa et al., 2003; Karsburg et al., 2003). Low, actual values of fat thickness are not very accurately estimated by ultrasound. They tend to be overestimated, mainly due to misinterpretation of connective tissue layers that normally develop within the fat tissue (Smith et al., 1992).

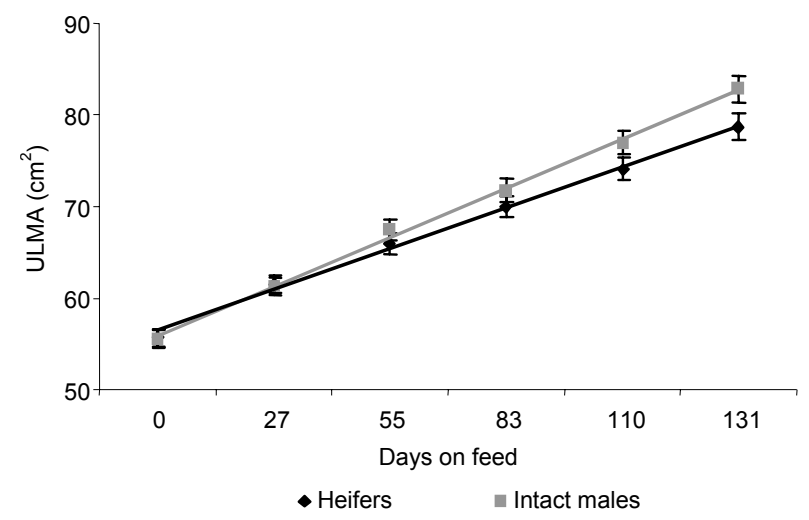

Figure 2 - Means and standard errors of ultrasound Longissimus muscle area (ULMA) as a function of days on feeding.

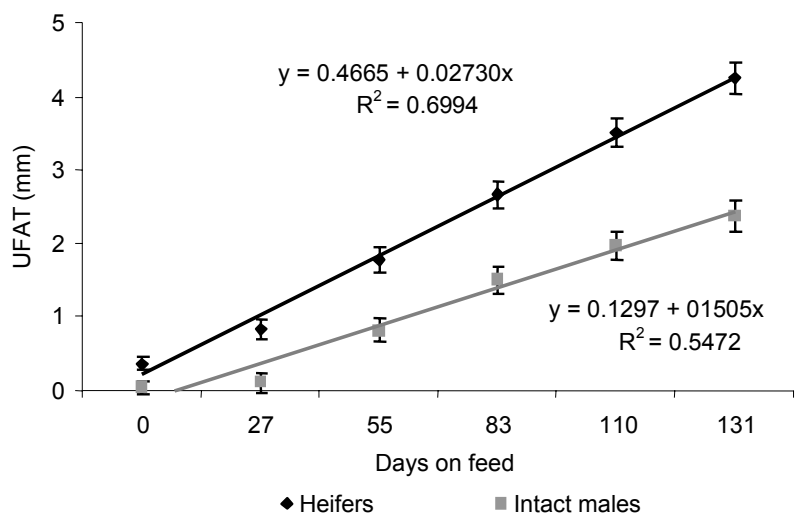

Figure 3 - Means and standard errors for ultrasound subcutaneous fat thickness (UFAT) as a function of days on feeding.

Table 2 - Regression equations of live weight, ultrasound Longissimus muscle area (ULMA) and backfat thickness (UFAT) as function of time on feed.

\begin{tabular}{|c|c|c|c|c|c|}
\hline Trait & & Intercept & Slope & $\mathrm{R}^{2}$ & RMSE \\
\hline \multirow[t]{2}{*}{ Live weight, $\mathrm{kg}$} & Heifers & $260.97 \pm 4.07$ & $0.950 \pm 0.03$ & 0.96 & 10.25 \\
\hline & Intact males & $260.97 \pm 4.07$ & $1.338 \pm 0.03$ & 0.93 & 17.49 \\
\hline \multirow[t]{2}{*}{ ULMA, $\mathrm{cm}^{2}$} & Heifers & $55.97 \pm 0.67$ & $0.175 \pm 0.01$ & 0.73 & 4.70 \\
\hline & Intact males & $55.97 \pm 0.67$ & $0.205 \pm 0.01$ & 0.63 & 7.10 \\
\hline \multirow[t]{2}{*}{ UFAT, mm } & Heifers & $0.51 \pm 0.10$ & $0.029 \pm 0.01$ & 0.78 & 0.78 \\
\hline & Intact males & $0.21 \pm 0.10$ & $0.017 \pm 0.01$ & 0.59 & 0.77 \\
\hline
\end{tabular}

RMSE - root mean square error 
The influence of sex on carcass traits is well known. The greatest expression of sex is related to fat deposition, in that heifers start fat deposition at lighter weights than castrated and intact males (Berg \& Butterfield, 1979).

UFAT increased linearly $(P<0.0001)$ with days on feeding in heifers and intact males. Both the intercept and slope of the regression equation (Table 2) were different for heifers and intact males $(P=0.0485$ and $P<0.0001$, respectively), with greater values for heifers. Linear association between subcutaneous fat thickness and days on feed also was observed by Silva (2002), who showed that for Nellore young bulls, UFAT increased at a higher rate $\left(0.021 \mathrm{~mm}^{-1 a y}{ }^{-1}\right)$ than the values observed in this work $\left(0.017 \mathrm{~mm}\right.$ day $\left.^{-1}\right)$. Similar linear increases were also observed for Brangus intact males (Silva et al., 2003) and Limousin-Angus-cross heifers (Nash et al., 2000).

\section{ACKNOWLEDGEMENTS}

To Fazenda Morro Vermelho, Ribeirão Claro, PR, Brazil for financial support and to Frigorífico MARFRIG for slaughtering the animals and assisting with carcass evaluations.

\section{REFERENCES}

BERG, R.T.; BUTERFIELD, R.M. Nuevos conceptos sobre el desarollo del ganado vacuno. Zaragoza: Acríbia, 1979. 297p.

CREWS, D.H.; SHANNON, N.H.; CREWS, R.E.; KEMP, R.A. Weaning, yearling, and preharvest ultrasound measures of fat and muscle area in steers, bulls, and heifers. Journal of Animal Science, v.80, p.28172824, 2002.

KARSBURG, J.H.; FERRAZ, J.B.; SILVA, S.L.; PETERNELLI, M.; BRAGA, J.G.; FORMIGONI, I.B.; HERLING, V.R. Carcass traits evaluation measured by ultrasound of Nellore cattle in pastures of (Brachiaria Brizantha) submitted to different forrage alowance. In: WORLD CONFERENCE ON ANIMAL PRODUCTION, 9., Porto Alegre, 2003. Proceedings. Porto Alegre: Federação das Indústrias do Estado do Rio Grande do Sul, 2003. 1 CD-ROM.
LUCHIARI FILHO, A. Characterization and prediction of carcass cutability traits of zebu and crossbreed types of cattle produced in southeast Brazil. Manhattan: Kansas State University, 1986. 89p. (Thesis - Doctor of Philosophy).

MAY, S.G.; DOLEZAL, H.G.; GILL, D.R.; RAY, F.K.; BUCHANAN, D.S. Effects of days fed, carcass grade traits, and subcutaneous fat removal on postmortem muscle characteristics and beef palatability. Journal of Animal Science, v.70, p.444-453, 1992.

NASH, S.A.; HARRISON, S.N.; PACKHAM, J.H.; PANTING, R.R.; DUCKETT, S.K. Case study: Monitoring changes in carcass quality across time-on-feed using real-time ultrasound to optimize marketing endpoints. The Professional Animal Scientist, v.16, p.202-205, 2000.

OWENS, F.N.; GARDNER, B.A. A review of the impact of feedlot management and nutrition on carcass measurements of feedlot cattle. In: ANNUAL MEETING OF AMERICAN SOCIETY OF ANIMAL SCIENCE, Indianapolis, 1999. Proceedings. Indianapolis: Indianapolis Convention Center, 1999. 18p. Available at: http://www.asas.org/JAS/ journal.asp? Society $=$ asas\&month $=0 \&$ year $=0$.

SILVA, D.J. Análise de alimentos: métodos químicos e biológicos. Viçosa: UFV, 1998. 166p.

SILVA, S.L. Estimativa de características de carcaça e ponto ideal de abate por ultra-sonografia, em bovinos submetidos a diferentes níveis energéticos na ração. Pirassununga: USP/FZEA, 2002. 80p. (Dissertação - Mestrado)

SILVA, S.L.; LEME, P.R.; PEREIRA, A.S.C.; PUTRINO, S.M. Correlações entre características de carcaça avaliadas por ultra-som e pós-abate, em novilhos Nelore alimentados com altas proporções de concentrado. Revista Brasileira de Zootecnia, v.32, p.1236-1242, 2003.

SILVA, S.L.; LEME, P.R.; PUTRINO, S.M.; LANNA, D.P.D. Carcass traits of Brangus Young bulls fed four concentrate levels evaluated by ultrasound. Livestock for Rural Development, v.16, art. \#58, 2004. Available: http://www.cipav.org.co/lrrd/ 1rrd16/8/silv16058.htm

SMITH, M.T.; OLTJEN, J.W.; DOLEZAL, H.G.; GILL, D.R.; BEHRENS, B.R. Evaluation of ultrasound for prediction of carcass fat thickness and longissimus muscle area in feedlot steers. Journal of Animal Science, v.70, p.29-37, 1992.

SUGUISAWA, L.; MATTOS, W.R.S.; OLIVEIRA, H.N.; SILVEIRA, A.C.; ARRIGONI, M. B.; HADDAD, C.M.; CHARDULO, L.A.L.; MARTINS, C.L. Ultrasonography as a predicting tool for carcass traits of Young bulls. Scientia Agricola, v.60, p.779-784, 2003.

WEISS, W.P.; CONRAD, H.R.; PIERRE, N.R. St. A theoretical-based model for predicting total digestible nutrient values of forages and concentrates. Animal Feed Science and Technology, v.39, p.95-110, 1992.

Received March 10, 2004

Accepted June 29, 2005 